УДК 316.6:316.35

М. М. Слюсаревський

\title{
НАУКОВІ УЯВЛЕННЯ ПРО СКЛАДОВІ ПСИХІКИ ВЕЛИКИХ ГРУП: СПРОБА "ІНВЕНТАРИЗАЦІї"
}

Обговорюється проблема впорядкування наукових уявлень про будову психіки великих груп, вирішення якої, на думку автора, передбачає такі етапи: своєрідну інвентаризацію, тобто цілісний опис цих уявлень; їх систематизацію; розроблення відповідної рамкової теорії. Статтю присвячено вирішенню завдань першого етапу. Проаналізовано основні підходи до виокремлення та класифікації структурних елементів психіки великих груп. Показано, що вони хибують на однобічність, тому наукові уявлення про номенклатуру складових психіки великої групи потребують поглиблення і розширення. У структурі психіки великих груп виділено елементи, які доцільно тлумачити у двох аспектах: 1) як типові для представників певної великої групи; 2) як такі, що бодай почасти мають надіндивідуальний характер. Поряд із цими елементами розглянуто групові феномени, що $є$ надіндивідуальними за самою своєю природою; для їх означення уведено поняття "незвідні феномени психіки великих груп". Особливий акцент зроблено на структурно-функціональній розбалансованості проаналізованих наукових уявлень. Стверджується, що для їх збалансування значно більше уваги слід приділяти проблематиці: а) групових психічних станів і групових психічних процесів; б) сфері групового несвідомого. Ця проблематика має знайти належне визнання, зокрема в навчальній літературі для студентів.

Ключові слова: велика група, структура психіки великої групи, незвідні феномени психіки великих груп, групові психічні властивості, стани та процеси, групова свідомість, групове несвідоме.

M. M. Slyusarevskyy

\section{SCIENTIFIC IDEAS ON PSYCHICS COMPONENTS OF LARGE GROUPS: INVENTORIZATION ATTEMPT}

It is discussed the problem of scientific ideas organizing on the psyche structure of large groups, the solution of which involves the following stages: some kind of inventorization, that is, a holistic description of these ideas; their systematization; the development of an appropriate framework theory. The article is dedicated to the solving problems of the first stage. The basic approaches to the separation and classification of structural elements of the large groups psyche are analyzed. It is shown that this approaches fail to be one-sided, so scientific ideas about the nomenclature of a large group psyche's components need to be deepened and expanded. In the structure of a large groups psyche, there are the elements that are appropriate to be interpreted by two aspects: 1 ) as typical for representatives of a certain large group; 2 ) as such, which at least partially have supra-individual characteristics. Along with these elements, group phenomena, which are supra-individual by their nature, are 
considered; for their definition, the concept of "unknowable phenomena of the large groups psyche" is introduced. A special emphasis is placed on the structure-functional imbalance of the analyzed scientific ideas. It is argued that for their balancing much more attention should be paid to the problems of: a) group mental states and group mental processes; b) group unconscious sphere. This problem has to be well recognized, especially in the educational literature for students.

Key words: large group, structure of a large group psyche, unknowable phenomena of the large groups psyche, psychological properties, states and processes of groups, group consciousness, group unconscious.

Постановка проблеми. Психологія великих груп належить до найменш розроблених розділів соціальної психології. Відразу зауважимо, що під великими групами ми маємо на увазі відносно сталі сукупності людей, а не так звані тимчасові контактні групи (натовпи, юрби), уже саме віднесення яких до великих груп (а не, скажімо, до середніх), на наш погляд, є питанням дискусійним, таким, що потребує окремого обговорення. Отже, йдеться про психологію більш чи менш сталих великих груп, що виокремлюються за соціально-економічними, національними, релігійними, професійними, гендерними та іншими реально значущими для суспільства та його членів ознаками.

Хоча на рубежі XIX - XX століть, коли відбувалося становлення соціальної психології як окремої наукової дисципліни, великі групи були одним з головних об'єктів інтересу їі батьків-засновників, передусім Вільгельма Вундта та Гюстава Лебона, у подальшому групова проблематика соціально-психологічних досліджень звузилася фактично лише до малих груп. Причини цього звуження ми неодноразово аналізували у своїх попередніх публікаціях [1; 2], тому зараз обмежимося констатацією того факту, що й на сьогоднішній день великі групи як такі не посідають пріоритетних позицій у світовій соціально-психологічній науці. Причому не тільки в її американській традиції, яка майже не послуговується навіть терміном “велика група" [3], а й у західноєвропейській. Аби переконатись у справедливості цього твердження, досить звернутися до навчальної літератури, підготовленої маститими західноєвропейськими авторами, де годі шукати розділів, присвячених великим групам (див., напр., [4]). У Західній Свропі до наукових пріоритетів належить вивчення лише окремих атрибутів психіки великих груп, передусім соціальних уявлень [5-7], що зумовлено популярністю теорії цього феномена, яку розробив С. Московічі, запропонувавши водночас і метод його дослідження [8]. Тому перебільшенням видаються твердження про те, що в західноєвропейській традиції проблематика великих груп переживає своє друге народження [9]. Перебільшенням $є$ й запевнення багатьох російських авторів у тому, що в колишньому Радянському Союзі ця проблематика була, мовляв, провідною ще від початку 1960-х років, коли на радянських теренах тільки-но почала 
відроджуватися соціальна психологія [9-11]. Відповідно до ідеологічних постулатів марксизму пріоритетність великих груп (насамперед, зрозуміло, класів) як об’єктів соціально-психологічного пізнання справді постійно декларувалася. Але ці декларації здебільшого не підкріплювалися дослідницькою практикою: як і на Заході, радянські соціальні психологи вивчали переважно ті ж малі і середні групи, іменуючи їх колективами. Лише після розвалу СРСР у пострадянських країнах, зокрема в Україні та Російській Федерації, розпочалося систематичне проведення емпіричних досліджень соціально-психологічного гатунку, так чи інакше пов'язаних з великими групами або й безпосередньо їм присвячених. Проте скільки-небудь цілісної картини, яка б відображала “психологічне обличчя" великих груп, так і не склалося.

Наукові уявлення про складові психіки великої групи (їню номенклатуру, співвідношення, взаємозв'язок тощо) характеризуються фрагментарністю і неповнотою, недостатньою узгодженістю, а то й суперечливістю, надмірними генералізаціями і водночас очевидними спрощеннями, елімінацією незручних для позитивістського тлумачення точок зору. Це, своєю чергою, негативно позначається на стані емпіричного дослідження психологічних феноменів, притаманних великим групам. Дослідник робить вибір на користь того чи того феномена, як правило, довільно, нерідко навмання, що значно ускладнює осмислення отриманих даних, звужує поле їх інтерпретації як у теоретичному, так і практичному контексті. Через те постає потреба якщо не зведення до спільного знаменника, то принаймні певного впорядкування наукових уявлень, які стосуються будови психіки великих груп, іiі складових ${ }^{1}$.

Аналіз останніх досліджень і публікацій. Переглянувши українсько- та російськомовні публікації на соціально-психологічні теми, оприлюднені протягом останнього десятиріччя, можна побачити, що серед них порівняно небагато тих, котрі бодай якоюсь мірою можна віднести до психології великих груп. Це вже саме по собі є, на наш погляд, симптоматичним. Але справа, звичайно, не тільки в кількості публікацій.

Досліджуючи психологічні особливості великих груп (соціальних, професійних, етнонаціональних, мовних, територіальних, релігійних, гендерних, вікових, поколінських тощо), автори публікацій послуговуються найчастіше такими поняттями, як ідентичність - соціальна, етнонаціональна, мовна, релігійна [12-15], цінності та ціннісні орієнтації

\footnotetext{
${ }^{1}$ Ми ведемо мову лише про складові психіки великих груп, свідомо оминаючи питання про іiї природу та онтологічний статус. Як уже зазначалося нами раніше, це питання наразі не має задовільного розв'язку, але його нерозв'язаність у найближчій перспективі в жодному разі не повинна стояти на заваді дослідженню тих аспектів психіки великих груп, які піддаються вивченню наявними нині пізнавальними засобами [2].
} 
[16-22], соціальні уявлення та уявлення в традиційному, загальнопсихологічному, розумінні [23-28], менталітет і ментальність [29-33], образ - світу, мови, іншої групи [34-36]. Рідше використовуються поняття картини світу [19; 37], історичної та колективної пам'яті [25; 38], соціального та рефлексивного капіталу [39; 40], способу життя [35], стилю життя [41], громадської думки [42], настановлень [28], ставлень [43; 44], очікувань [45], норм [17; 46], стереотипів [47]; колективних смислів [48], соціальних вірувань [49], соціально-психологічних властивостей [50]. При цьому досліджуються здебільшого психологічні характеристики членів тих чи тих великих груп, а не власне групові феномени. Аналіз власне групових феноменів тією чи іншою мірою представлений лише публікаціями, де йдеться про соціальні уявлення, менталітет, колективні смисли, історичну та колективну пам'ять, громадську думку, соціальний та рефлексивний капітал групи.

Наукові уявлення про складові психіки великих груп у більшості розглянутих публікацій спеціально не обговорюються і загалом не виходять за змістові межі, визначені популярними на пострадянському просторі підручниками та навчальними посібниками із соціальної психології $[10 ; 11] .3$ огляду на це вважаємо правомірним, по-перше, здійснювати подальший розгляд проблеми переважно на основі цих підручників та навчальних посібників, а по-друге, залучати до розгляду ті публікації, які в суто часовому вимірі не належать до останніх (вони побчили світ значно раніше, ніж розглянуті вище), але залишаються актуальними, оскільки містять вагомі теоретичні напрацювання 3 питань психології великих груп, що істотно розширюють закріплені в навчальній літературі наукові уявлення, досліджуючи ті аспекти групової психіки, яких ця література воліє “не помічати”, і тим самим заповнюють наявні в ній прогалини. Маємо на увазі, наприклад, праці О. Донченко [51; 52] та Л. Каширіної [53].

Невирішені частини загальної проблеми. Мабуть, зайве доводити, що впорядкуванню наукових уявлень, про які тут ідеться, найкраще прислужилась би певна рамкова теорія, якби така була. Але, як визнають чи не найавторитетніші в цій галузі вчені А. Журавльов i Т. Ємельянова, психологія великих сталих груп досі не має у своєму розпорядженні “жодного атрибута усталеної теорії” [54, с. 6]. Отже, загальна проблема вбачається в побудові такої теорії.

На нашу думку, рухатися в напрямку її створення слід шляхом послідовного наближення до неї. Це передбачає такі етапи вирішення загальної проблеми:

1) своєрідна інвентаризація, тобто по можливості цілісний опис наявних сьогодні наукових уявлень про складові психіки великих груп;

2) систематизація описаних уявлень;

3) розроблення на цій основі відповідної теорії так званого верхнього рівня, що може стати основою для висунення низки теорій се- 
реднього і нижнього рівнів, здатних стимулювати взаємно несуперечливі емпіричні дослідження.

Вирішенню завдань першого етапу й присвячено що статтю.

Мета статті, як і заявлено в іiі назві, полягає в “інвентаризації” традиційно усталених та порівняно нових чи принаймні менш поширених наукових уявлень про складові психіки великих груп. При цьому ми не намагатимемося згадати всі можливі складові, а зосередимо головну увагу на тих із них, що видаються найбільш показовими як у плані репрезентації будови психіки великої групи, так і з погляду відображення загальної логіки здійснюваного опису, яку ми маємо намір застосувати.

Виклад основного матеріалу дослідження. Найбільш відомі підходи до виокремлення та класифікації структурних елементів психіки великих груп можна унаочнити у вигляді таблиці, яку наведено нижче. Розгляньмо найістотніші особливості цих підходів.

Перший із них висунуто Г. Андреєвою. Згідно з ним елементи психіки великої групи пропонується диференціювати на підставі їхньої належності до трьох основних класів психічних явищ, якими є, як відомо, психічні властивості, психічні процеси і психічні стани [10, с. 149]. Тобто психіка великої групи мислиться як така, що $є$ за будовою ізоморфною психіці індивіда. Її складають відповідно групові психічні властивості, групові психічні процеси, групові психічні стани. Якими саме елементами можна “наповнити” кожен із класів групових психічних явищ, Г. Андреєва не вказує, але це неважко зробити. До властивостей можна віднести, наприклад, групові потреби, інтереси, настрої, настановлення; до процесів - соціальне сприймання і мислення, групову ідентифікацію (як процес формування понять “ми” i “вони”, “наші” i “чужі”); до станів - групову мобілізованість і соціальну напруженість, масову паніку тощо.

Таблиия

Основні підходи до класифікації структурних елементів психіки великих груп

\begin{tabular}{|c|c|}
\hline Підстава класифікації & Структурні елементи \\
\hline різні класи психічних явищ & $\begin{array}{l}\text { - } \text { групові психічні властивості } \\
\text { - групові психічні процеси } \\
\text { - групові психічні стани } \\
\end{array}$ \\
\hline $\begin{array}{l}\text { аналогія зі сферами психічного, які } \\
\text { розмежовуються в загальнопсихоло- } \\
\text { гічних теоріях особистості }\end{array}$ & $\begin{array}{l}\text { - когнітивна сфера групи } \\
\text { - потребово-мотиваційна сфера групи } \\
\text { - афективна сфера групи } \\
\text { - } \text { регулятивно-вольова сфера групи }\end{array}$ \\
\hline $\begin{array}{l}\text { критерій сталості соціально-психо- } \\
\text { логічних характеристик (традицій- } \\
\text { ний для етнології та етнічної психо- } \\
\text { логії) }\end{array}$ & $\begin{array}{l}\text { • психічний склад групи } \\
\text { • емоційна сфера групи }\end{array}$ \\
\hline
\end{tabular}


Інакший підхід до класифікації структурних елементів психіки великих груп запропонувала К. Шорохова. Цей підхід, який набув значно більшої популярності, теж базується на принципі ізоморфності індивідуальної і групової психіки, котрого, як побачимо далі, дотримуються й інші автори. Складові психіки великої групи у межах цього підходу класифікуються за аналогією з поширеним у загальнопсихологічних теоріях особистості розмежуванням чотирьох сфер психічного - когнітивної, мотивачійної, афективної та регулятивно-вольової [55]. До когнітивної сфери психіки великих груп відносять громадську думку, соціальні уявлення, соціальне мислення, менталітет, до мотиваційної групові потреби, інтереси, цінності, ідеали, так звані життєві орієнтації членів групи, до афективної - соціальні почуття, емоції, суспільні настрої, до регулятивно-вольової сфери - цілі групової поведінки та способи їх досягнення [11, с. 226-230]. Напевно, логічним буде доповнити регулятивно-вольову сферу також низкою властивостей групи на кшталт дисциплінованості, психологічної стійкості, рішучості тощо.

Ще один підхід, що претендує на вироблення загальних уявлень про структуру психіки великих груп, сформувався спочатку в галузях етнології та етнічної психології (А. Горячева, Ю. Бромлей та ін.). Згідно 3 ним у структурі психіки етнічної групи (як правило, йдеться про націю) прийнято виділяти дві підструктури: 1) психічний склад цієї групи, у якому вбачають відносно стійке утворення, що складається 3 таких елементів, як національний (етнічний) характер, звичаї, традиції; 2) емоиійну сферу, котру тлумачать як більш рухоме утворення, куди входять групові настрої, “ми-почуття”, потреби, інтереси. Окрім того, до емоційної сфери інколи відносять етнічну ідентичність, етнічну самосвідомість та етнічні стереотипи [10, с. 159], що, втім, видається спірним. Адже попри все своє емоційне наснаження як самосвідомість, так і стереотипи мають усе ж таки когнітивну основу, та й ідентичність важко уявити як суто емоційний феномен.

У подальшому цей підхід, запозичений з етнології та етнопсихології, було екстрапольовано й на інші великі групи, зокрема на соціальні та професійні $[10 ; 56]$. Така його екстраполяція потягла за собою варіювання окремих понять. Наприклад, замість національного характеру почали говорити про соціальний характер, наповнюючи це поняття специфічним, “класовим”, змістом".

Як бачимо, в усіх розглянутих підходах фігурує багато термінів, аналогічних тим, за допомогою яких описують психіку окремого

\footnotetext{
${ }^{1}$ Побіжно зауважимо, що поняття "соціальний характер” увів ще Е. Фромм, але співвідносив його не з тими чи тими великими групами, а з різними історичними епохами в житті суспільства.
} 
індивіда (групові потреби, інтереси тощо). Вони, думається, спеціальних тлумачень не потребують. Але трапляються й терміни, яких зазвичай не використовує загальна психологія. До них належить, зокрема, термін “життєві орієнтаціï”, яким, нагадаємо, означують один із структурних елементів мотиваційної сфери великих груп. Під життєвими орієнтаціями членів великої групи розуміють систему преференцій, що втілюються в усвідомленому чи, можливо, й несвідомому виборі форм групової поведінки в конкретних соціальних умовах.

Прийнято вважати, що життєві орієнтації реалізуються в певному способі життя - не лише окремих людей, які складають велику групу, а й групи в цілому. Спосіб життя визначають як сукупність усталених (типових для певних соціально-економічних відносин) форм життєдіяльності народів, класів, соціальних груп, окремих людей у матеріальній, духовній, суспільно-політичній та сімейно-побутовій сферах. У ньому вбачають цілісну характеристику психологічних особливостей тієї чи тієї великої групи [11, с. 232].

Як не цілком тотожні індивідуально-психологічним мисляться і ті елементи психіки великих груп, для опису яких використовують терміни загальнопсихологічного штибу, доповнені означеннями "груповий” або “суспільний”. Так, суспільні настрої, якими переймаються великі групи, згідно з концепцією Б. Паригіна, відрізняються від індивідуальних своєю переважно соціальною зумовленістю, більшим ступенем соціальної детермінованості. У суспільних настроях чинник особистого фізичного та психічного самопочуття, під дією якого виникають індивідуальні настрої, відходить на задній план, поступаючись місцем соціальним чинникам [57].

Нової, системної, якості набуває у груповому контексті також ідентичність індивідів як членів групи. У цьому плані безперечний інтерес становить дещо, може, й недоладне з лінгвістичної точки зору, але теоретично обгрунтоване розмежування П. Горностаєм понять “групова ідентичність" та “ідентичність групи”. Під груповою ідентичністю він розуміє властивість індивіда, який ідентифікує себе з певною групою, усвідомлює себе ії членом, а під ідентичністю групи - характеристику цієї групи як сукупного суб'єкта, що відповідає більш високому рівневі їі розвитку [58, с. 115].

Отже, ті елементи психіки великих груп, що є аналогічними індивідуально-психологічним, доцільно розглядати у двох аспектах:

1) як типові для представників певної групи;

2) як такі, що бодай почасти мають надіндивідуальний характер, тобто властиві лише групі в цілому, а не ії окремим членам.

Інакше кажучи, можна вивчати, наприклад, потреби чи інтереси як риси особистості, що є типовим членом своєї групи, з одного боку, i власне групові потреби чи інтереси, які породжуються умовами ії спіль- 
ного функціонування, з другого. У цьому, другому, аспекті прикладом можуть бути, скажімо, національні інтереси, що визначають пріоритети зовнішньої політики держави, які часом доволі складно й далеко неоднозначно поєднуються з індивідуальними інтересами громадян. Індивідуально-типовий і надіндивідуальний виміри мають, напевно, й картина світу, властива тій чи тій великій групі, іiі соціальні вірування, стиль життя, соціальний та рефлексивний капітал тощо.

Проте поряд із такими “двоаспектними” елементами у психіці великих груп потрібно виокремлювати також феномени, що є надіндивідуальними, так би мовити, за визначенням. За самою своєю природою вони в жодному разі не зводяться до феноменів індивідуальних, бодай i типових. Тож будемо називати їх незвідними і розглянемо окремо.

\section{Незвідні феномени психіки великих груп}

Серед незвідних феноменів заслуговують на увагу передусім:

- громадська думка;

- соціальні уявлення групи;

- історична (колективна) пам'ять;

- групові традиції та звичаї.

Громадська думка наразі не має однозначного тлумачення. Налічується понад два десятки її визначень. Найбільш прийнятним із них, мабуть, можна вважати те, що трактує громадську думку як сукупність колективних оцінних суджень великих груп, у яких виявляється їхне ставлення до змісту та способів вирішення суспільних проблем, котрі стосуються їхніх спільних інтересів [59, с. 16]. Однак це визначення не $є$ загальновизнаним. Унаслідок низки причин теоретичного плану, зокрема недостатньої розробленості поняттєвого апарату теорії великих груп, поняття громадської думки нерідко тлумачиться значно ширше. Під нею часто розуміють не лише думку як таку, а й те, що належить до потребово-мотиваційної сфери людей, - їхні емоції, настрої, пристрасті.

Утім, хоч як би тлумачити громадську думку, ïi сутнісна ознака полягає в надіндивідуальному, надособистісному характері. Громадська думка хоча й може усвідомлюватись (привласнюватися) окремими індивідами як їхні власні міркування чи умовиводи, завжди $є$ рівнодійовою найрізноманітніших впливів і взаємовпливів. Тобто $є$ груповим, незвідним феноменом.

Природна суперечливість соціальних подій і явищ породжує відповідно й певну суперечливість громадської думки, яка їх відображає. Тому виділяють два різновиди громадської думки: моністичну (більшменш одностайну) і плюралістичну, що складається з багатьох поглядів, часто далеких один від одного. Переважає зазвичай останній різновид, а моністичною громадська думка стає на завершальному етапі свого формування, коли у великій групі виробляється певна узгоджена позиція. 
Суперечливість громадської думки виявляється й у тому, що вона часом містить як істинні, так і хибні судження, може мати як конструктивний, так і деструктивний потенціал 3 погляду завдань суспільного поступу, деформується під дією маніпулятивних технологій. Як засвідчують масові опитування населення, наочною ілюстрацією такої суперечливості $є$ ставлення переважної більшості громадян України до освітніх реформ та інновацій, одні з яких схвалюються, інші ж, навпаки, сприймаються насторожено або й викликають відвертий спротив [60].

Складаючись у процесі колективного мислення людей, громадська думка може бути доволі стабільною, інертною, але головними ії рисами все ж $є$ плинність та змінюваність. Певна громадська думка виникає 3 приводу якоїсь конкретної проблеми й існує доти, доки ця проблема залишається актуальною (не вирішеною). Ї̈і логічні межі, зміст і характер зумовлюються пізнавальними можливостями групової та суспільної свідомості, наявним інтелектуальним рівнем і соціокультурними традиціями великих груп, доступністю для громадян потрібної інформації, розвитком системи мас-медіа та іншими подібними чинниками.

Нині громадська думка вивчається різними науками. У соціології навіть склалася спеціальна соціологічна теорія - соціологія громадської думки [61]. У iї межах громадську думку розглядають не лише як елемент групової, суспільної чи масової свідомості, а й також як певний соціальний інститут. Такий погляд на неї, безперечно, має право на існування. Адже громадська думка справді виявляє, причому дедалі більше, виразні ознаки інституалізації, відіграючи надзвичайно важливу роль у суспільному житті, у відносинах народу і влади. Одна з прикметних ознак інституалізації громадської думки - створення та діяльність у багатьох країнах світу численних центрів 3 її вивчення. Їхні дослідження, з одного боку, сприяють узгодженню позицій громадян, 3 другого - надають органам державної влади інформацію, необхідну для підтримання зворотного зв'язку з громадянським суспільством.

Проте інтерпретуючи громадську думку як соціальний інститут, не слід забувати водночас, що за своєю природою вона є феноменом надіндивідуальної психіки (групової і суспільної), посідає в іiї структурі певне місце, а саме місце серед структурних елементів, які прийнято називати груповою та суспільною свідомістю. Цей феномен порівняно легко, принаймні значно легше, ніж інші елементи свідомості, а тим паче групового несвідомого, піддається емпіричному вивченню і тому найчастіше потрапляє в поле зору дослідників. Але інтенсивність досліджень громадської думки не означає, що до неї можна звести все багатство й багатомірність свідомості великих груп і суспільства в цілому. Як дотепно зауважувала російський соціолог Т. Заславська, “якщо уявити собі суспільство у вигляді ємкості, наповненої рідиною, то громадська думка - не більш ніж верхня плівка" [62]. 
Отже, поняття громадської думки не варто надмірно генералізувати, підводячи під нього інші групові феномени. Це актуалізує проблему ії співвіднесення з пов'язаними 3 нею, але не тотожними їй феноменами. Спробу такого співвіднесення здійснив український соціолог В. Оссовський, який показав зокрема, що громадську думку як переважно раціональне судження слід відрізняти од розглянутих вище суспільних настроїв, у котрих домінує емоційний компонент. 3 огляду на це громадська думка у своєму актуальному існуванні перебуває ніби між двома полюсами: вірогідним знанням, на яке вона намагається спиратися, і суспільним настроєм, наближаючись до одного 3 полюсів залежно від ситуації.

На наш погляд, громадську думку можна співвіднести також із соціальними уявленнями, припустивши, що вони можуть, 3 одного боку, лежати в основі іiі формування, а з другого - вбирати в себе ії відносно стабільні, інертні фрагменти. Теорію соціальних уявлень (соціальних репрезентацій), як уже зазначалося, розробив С. Московічі [8]. Ці уявлення визначено в ній як концептуалізовані утворення, що виникають у спільнотах (великих групах) за допомогою дискурсу. Вони становлять систему ідей, цінностей та практик, які виконують подвійну функцію: по-перше, забезпечують порядок, що дає можливість індивідам орієнтуватись у світі та впливати на нього; по-друге, уможливлюють комунікацію між членами спільноти завдяки наданню їм кодів соціального обміну.

Теорія соціальних уявлень відводить значну роль конструюванню людьми соціально репрезентованого світу. Московічі навіть стверджує, що соціальні уявлення - це не уявлення про об'єкт, які існують незалежно від нього: це і є об'єкт, який не може існувати незалежно від діючих соціальних суб'єктів.

3'являючись на авансцені історії замість прадавніх міфів та вірувань, соціальні уявлення складаються в сучасному світі на основі наукових теорій. Але наукові теорії функціонують у суспільному середовищі на рівні неспеціального дискурсу - здорового глузду. Індивіди, які не $є$ професіоналами в науці, видозмінюють та опрацьовують через спільну комунікацію оприявлені в теоріях ідеї, що видаються конститутивними для здорового глузду. До творення соціальних уявлень може долучатися кожна людина, оскільки існує символічний простір їх узгодження та розвитку. Проте соціальні уявлення, що суб' єктивно мають статус істини, не локалізуються в розумі окремого індивіда. Суб'єктами соціальних уявлень $\epsilon$ великі групи людей.

Незвідністю характеризуються також феномени історичної та колективної пам'яті, до речі, тісно пов'язані із соціальними уявленнями. Цю пов'язаність констатує, зокрема, Т. Смельянова, розглядаючи соціальне уявлення “як інструмент колективної пам'яті” [25]. 
Історична і колективна пам'ять - поняття не лише близькі, а й значною мірою синонімічні. Історична пам'ять завжди $є$ груповою, колективною. Адже простягається далеко за межі пам'яті автобіографічної (індивідуальної) і забезпечує трансляцію знань про минуле від покоління до покоління [38; 63; 64].

Історична пам'ять фіксується у формі не тільки більш чи менш вірогідних знань, а й культурних стереотипів, символів та міфологізованих уявлень і тому не може бути цілком об'єктивною. У ній закріплюється лише те, що сприймається великою групою як значуще для іiі життя. Маркери цієї суб'єктивної значущості часто мають архаїчний, архетипний характер. Осмислюючи своє минуле, велика група як колективний суб'єкт звертає увагу зазвичай на яскраву драматичну ситуацію і не зважає на тривалі та поступові суспільні процеси, що спричинилися до неї.

Особливістю історичної пам'яті є її хронотопність, тобто обов'язкова наявність у її змісті комплексу не лише часових, а й топонімічних характеристик. На думку М. Хальбвакса, історична пам'ять концентрується і репрезентується у так званих місцях пам'яті. Головна функція таких місць - збереження групової пам'яті. Більше того, вважається, що створення й усвідомлення місць пам'яті відіграє провідну роль у формуванні групової ідентичності. Досліджуючи зміну цих місць, можна простежити трансформацію історичної самосвідомості та колективної ідентичності тісї чи тієї великої групи [64].

У науковій літературі неодноразово порушувалося питання, чи $\epsilon$ історична пам'ять реально існуючим і стійким феноменом, а чи артефактом, до того ж недовговічним. За М. Фуко, минуле часто змінюється в сучасних дискурсах. Історична спадщина реінтегрується різними генераціями, тому жодні інтерпретаційні моделі не можуть бути фіксованими й усталеними. Запровадивши поняття “контрпам'ять”, учений у своїх працях сфокусував увагу на проблемі політичного маніпулювання комеморативними практиками, під якими розуміють комплекс ритуалів та церемоній, спрямованих на репрезентацію певного історичного наративу [65].

Надміру скептичні погляди на історичну пам'ять, звичайно, не слід абсолютизувати. Але треба водночас мати на увазі, що проблема маніпулювання нею справді існує. В усі часи держави були активними модераторами історичного наративу, вдавалися до так званих переписувань історії. Тому в усіх суспільствах зазвичай поширюється офіційна версія історії, вигідна для владних еліт. Але коли ця версія занадто відхиляється від “народної”, з'являється природна загроза викриття ії недостовірності. У таких випадках поряд з офіційними побутують альтернативні інтерпретації історичних подій, адже духовний досвід поколінь, спогади про буття роду, національні традиції, міфи та легенди, що входять 
до складу історичної пам'яті, перебувають поза межами державного впливу. На цій основі виникає конфлікт інтерпретацій однієї чи кількох історичних подій, які часто мають характер колективної психотравми, що потребує емоційного відреагування. Тоді історична пам'ять може ставати не об'єднувальним началом, а дезінтегрувальним чинником. Так, у підрадянській Україні зазомбована офіційною пропагандою частина населення не визнавала Голодомору, одначе в іншій частині української людності спогади його жертв та очевидців повсякчас передавалися усним способом від старших поколінь до молодших. Відгомін цього конфлікту інтерпретацій історії, на жаль, докотився й до наших днів.

Проте "переписування історії, їі офіціозні тлумачення - не єдина форма маніпулювання історичною пам'яттю. Авторитарні режими i реакційні політичні сили перманентно вдаються до ескалації певних аспектів історичної пам' яті з метою розпалювання ненависті політично некомпетентних, а часом і маргінальних верств населення до окремих соціальних груп, інших країн і народів. Ненависть до цих соціальних груп, країн i народів розпалюється за допомогою їх неправомірної, штучної ідентифікації з ворогами, зловісний образ котрих склався в історичній пам'яті. Саме для цього російська пропаганда та проросійські сили в Україні називають патріотично налаштованих українців “фашистами”, а українську владу - “хунтою” тощо.

Українська дослідниця Ю. Зерній кваліфікує сучасний стан історичної пам'яті українців як кризовий. Вияви кризи простежуються у співіснуванні в колективній свідомості різних проекцій українського минулого: власне української і проімперської, що містить малоросійський, східнослов'янський та радянський компоненти. Ці антагоністичні проекції зумовлюють амбівалентність історичної свідомості народу, прикладом якої є ставлення до свят. Переважна більшість населення святкує і радянські, й українські, і релігійні свята, навіть ті, які вочевидь суперечать одне одному. Утім, імовірно, що так триватиме недовго. Можна сподіватися, що за мінімізації спроб маніпулювання історичною пам'яттю, а також у міру знаходження та реалізації адекватних способів емоційного відреагування на колективні психотравми історична пам'ять українського суспільства відновить свою цілісність та несуперечливість [66].

Історична пам'ять має в житті великих груп важливе значення ще й тому, що вона $є$ необхідною підвалиною формування традицій, яких дотримуються ці групи і без яких їхнє групове функціонування було б, мабуть, неможливим. Під традицією розуміють певний узаконений спосіб відтворення правил та норм поведінки і взаємин людей, що склався історично під впливом тих чи тих умов життя. Традиції визначають загальний напрямок групового функціонування, у них реалізується спадкоємність соціально значущих форм поведінки в типових 
ситуаціях. Такі форми велика група свідомо культивує і підтримує в найрізноманітніших сферах своєї життєдіяльності [11, с. 231].

Поряд із традиціями поведінка людей у великих групах та міжгрупові відносини регулюються звичаями. Їх у соціальній психології трактують як своєрідні, неписані закони, суб'єктивно корисні шаблони поведінки, що дають змогу людям найкращим чином взаємодіяти одне 3 одним. Звичай - вельми близький до традиції незвідний феномен. Але на відміну від традицій, які можуть встановлюватись як неофіційно, так і цілком офіційно, втілюватись у діяльності суспільних та державних інститутів, звичаї формуються лише в народному досвіді і реалізуються тільки в ньому (тому існують, наприклад, наукові чи політичні традиції, але не звичаї). 3 іншого боку, традиція може закріплюватись як в обрядах, церемоніях та ритуалах, так і у звичаях. Тобто поняття звичаю вужче, ніж поняття традиції. При цьому потрібно враховувати, що за своїм характером звичаї, як і традиції, можуть бути не лише прогресивними, а й регресивними, ба навіть реакційними, викоренити які буває дуже складно.

Незвідними феноменами психіки великих груп є також їхні психічні стани. Але вони належать уже до іншого класу психічних явищ.

\section{Психічні стани великої групи}

Не зайвим буде нагадати, що поняття “психічний стан” у психологічній науці використовується для означення відносно статичних i водночас не надто тривалих моментів у функціонуванні психіки. Цим психічні стани відрізняються, з одного боку, від психічних властивостей, які є значно стійкішими утвореннями, повторюваними і закріпленими у структурі психіки, з другого - від психічних процесів, що мають динамічний характер. Попри свою недовговічність психічні стани посідають серед інших психічних явищ у певному сенсі центральне місце, оскільки виникають унаслідок перебігу психічних процесів і справляють істотний вплив на формування та розвиток психічних властивостей. Тому без вивчення психічних станів годі сподіватися на адекватне відтворення як індивідуальних, так і групових форм психічного. На жаль, проаналізувавши розглянуті вище елементи психіки великих груп, побачимо, що серед них наразі значно переважають психічні властивості і набагато менше уваги приділяється груповим психічним станам та процесам. Тобто в наукових уявленнях про психіку великої групи спостерігається структурно-функціональний дисбаланс.

Отже, як вельми позитивну тенденцію слід оцінювати той факт, що в останні десятиліття дещо активізувалися теоретичні та емпіричні дослідження з питань групових психічних станів (чого все ще не можна сказати про групові психічні процеси). Так, Л. Каширіна запропонувала статусно-рольову концепцію цих станів, які вона називає соціальнопсихологічними [53]. У межах цієї концепції під психічним станом 
великої групи розуміється надіндивідуальне інтегральне системне утворення, шзо відображає більш чи менш усвідомлене переживання групою як соціальним суб'єктом своєї статусно-рольової позиції у структурі суспільства. Навряд чи таке визначення можна вважати вичерпним і універсальним, придатним для ідентифікації будь-яких (усіх можливих) психічних станів великої групи. Проте певні підстави воно під собою, безперечно, має, охоплюючи ті випадки, коли груповий психічний стан справді виникає внаслідок суттєвих змін в умовах життєдіяльності групи, пов’язаних саме з її соціальним статусом, чинниками ролі та місця в суспільстві.

Як надіндивідуальний феномен, груповий психічний стан охоплює кожного, хто належить до даної групи. При цьому більш-менш тривале перебування в ньому спричинює кумулятивний ефект і позначається на індивідуально-психологічних процесах, станах, а згодом i на особистісних властивостях членів групи, змінює систему їніх ставлень до навколишньої дійсності.

Групові психічні стани, згідно з концепцією Л. Каширіної, розгортаються в континуумі відповідності-невідповідності домагань групи iii суспільному статусові, що в разі невідповідності викликає у членів групи когнітивний дисонанс. На підставі цього критерію - відсутності або наявності когнітивного дисонансу - правомірно розрізняти два види психічних станів великої групи - консонантні і дисонантні. Консонантні стани сприяють збереженню таких властивостей групи, як соціально схвалювані потреби, ціннісні орієнтації, настановлення, переконання. У груповій поведінці домінують конвенціональні внутрішньогрупові стосунки, позитивна трудова мотивація, співпраця, група активно виявляє свою суб'єктність, їі члени мають переважно інтернальний локус контролю, високі показники фізичного та психічного здоров'я. Дисонантні стани, навпаки, призводять до розмивання та втрати згаданих властивостей. Прикладами консонантних психічних станів великої групи можуть слугувати стани позитивних соціальних очікувань, віри у власні сили, святкового піднесення, дисонантних - стани тривоги, негативних очікувань, розчарування тощо.

Проте в “чистому” вигляді такі стани спостерігаються порівняно рідко. Частіше життєдіяльність великих груп супроводжують конвергентні психічні стани. Вони виникають, коли протягом певного часового періоду відбувається взаємонакладання (конвергенція) кількох групових психічних станів, що посилює їхній вплив на поведінку групи загалом та індивідів, які їі складають. Конвергенція консонантних станів оптимізує життєдіяльність великих груп, а конвергенція дисонантних станів дезорганізує іï або спрямовує в альтернативне з погляду офіційно проголошених суспільних ідеологем річище.

Одним 3 найбільш вивчених і найчастіше обговорюваних надіндивідуальних психічних станів є соичіальна напруженість. Ії можна 
визначити як психічний стан соџіуму (суспільства, групи, спільноти), щзо виникає у відповідь на екстремальні впливи [67]. До виникнення соціальної напруженості спричинюються дестабілізаційні чинники (політичні, економічні, етнонаціональні, демографічні та ін.), пов'язані 3 кризовим розвитком соціальної системи, а також стихійні лиха, пандемії інфекційних захворювань, техногенні катастрофи тощо, які призводять до загострення суспільних суперечностей. Соціальна напруженість є колективною реакцією соціуму на зміни в умовах життєдіяльності, що насправді становлять загрозу реалізації значущих потреб і життєвих цілей соціальних суб'єктів, а то й самому їхньому існуванню, або під цим кутом зору сприймаються. Наслідками виникнення/підвищення соціальної напруженості можуть бути негативні суспільні настрої, посилення недовіри до властей, а також ажіотажний попит на товари першої необхідності, зростання злочинності, зниження народжуваності та інші вияви деструктивної індивідуальної і групової поведінки. При цьому наслідки виникнення соціальної напруженості стають водночас причинами її дальшого підвищення.

У разі граничного зростання соціальна напруженість таїть у собі небезпеку соціального вибуху - швидкоплинного, хаотичного процесу руйнування соціальної системи, що супроводжується масовими насильницькими діями. Іншим наслідком граничного зростання соціальної напруженості (якщо вона не “розряджається" в активних діях і не знімається позитивними змінами в суспільному житті) може бути довготривале збайдужіння людей, згасання політичної та економічної активності, дезінтеграція спільнот, суспільна апатія.

Соціальна напруженість є своєрідним надперсональним аналогом індивідуально-психологічних станів, що описуються психологами в термінах дистресу та фрустрації і залежно від обставин виливаються в агресію чи депресію. Утім, попри генетичну спорідненість із такими індивідуально-психологічними станами, яким властивий високоіндивідуалізований характер емоційних реакцій на стресогенні чинники (одна людина реагує на них гнівом, інша - страхом тощо), соціальна напруженість як психічний стан цілісного суспільного організму тяжіє до певної усередненості, деіндивідуалізованості.

Поняття “соціальна напруженість” було введене в науковий обіг у колишньому Радянському Союзі в період його розпаду (кінець 1980 початок 1990 років). За рубежем цим словосполученням (англ. social tension) послуговуються переважно інформаційні агентства, мас-медіа, у власне ж наукових контекстах західні вчені віддають перевагу іншим термінам, наприклад, тій же фрустрації. Близьким за змістом до соціальної напруженості $є$ також запроваджене американським соціологом Г. Блуммером поняття “соціальне занепокоєння” [68, с. 532].

Для ранніх праць російських та українських науковців 3 питань соціальної напруженості були характерними як різнотлумачення, так i 
надмірні розширення цього поняття. До нього, крім самого явища соціальної напруженості, нерідко включали також її об'єктивні причини та поведінкові наслідки. Нині ці недоліки ранніх інтерпретацій соціальної напруженості, які негативно позначалися на стані іiі емпіричних досліджень, поступово долаються. В українській соціальній психології розроблено оригінальну теорію соціальної напруженості [67], що базується на ситуаційному підході, який дав змогу побудувати діагностично-прогностичну модель іiі необхідних і достатніх показників. Проводяться моніторингові дослідження рівня і динаміки соціальної напруженості у всеукраїнському масштабі.

Наголосимо, що, уникаючи розширювальних тлумачень цього поняття, соціальну напруженість не слід плутати з груповими психічними станами мобілізаційного типу. Це стани трудового ентузіазму, мілітарної мобілізації, протестної готовності тощо. Як і соціальна напруженість, вони можуть мати стресове підгрунтя, але не дистресове i не фрустраційне. Незважаючи на різну модальність, такі стани характеризуються не дезорганізацією діяльності великої групи, а ії загальним емоційним піднесенням, прагненням до активного подолання наявних загроз і труднощів.

Особливий теоретичний і практичний інтерес становить проблема зв'язку соціальної напруженості з політичною поведінкою населення. Соціальну напруженість можна розглядати як потенціал і безпосередній чинник стихійного бунту (соціального вибуху), проте вона - лише одна 3 умов розгортання протестних акцій i, тим паче, протестних рухів. Масовим акціям протесту не обов'язково передує значне зростання соціальної напруженості, вони можуть відбуватись і за іiі помірного рівня, якщо в суспільстві $є$ попередньо сформовані, ригідно “затверділі” компоненти протестного потенціалу. Ба більше, в період наближення Помаранчевої революції на тлі зростання протестного потенціалу українського суспільства нами всупереч очікуванням було зафіксовано не підвищення, а, навпаки, зниження показників соціальної напруженості, що й зумовило переважно святковий, можна сказати, карнавальний перебіг подій на Майдані у 2004 році. І це різко відрізняє їхнє емоційне забарвлення від аналогічних за змістом подій зими 2013-2014 років.

Ще одним надіндивідуальним психічним станом негативного гатунку, який за руйнівними наслідками, напевно, перевершує всі інші, є стан масової паніки. Проте він більшою мірою властивий психології мас, ніж великих груп (про що говорить сама його назва). Тому характеристики цього стану доцільніше розглядати, обговорюючи не стільки групові, скільки масові психічні явища. Можна лише зауважити, що масова паніка, як і решта надіндивідуальних станів, має переважно або й виключно несвідому основу. І це нас наближає до такої суттєвої теми психології великих груп, як групове несвідоме, що й досі залишається майже обійденою увагою в підручниках із соціальної психології. 


\section{Несвідоме у психіці великої групи}

Сфера несвідомого в людській психіці, як відомо, не відділена глухою стіною від свідомості. Це стосується однаковою мірою як індивідуальної психіки, так і групової. Деякі елементи останньої, що виокремлюються в розглянутих класифікаціях складових психіки великих груп, є принаймні почасти неусвідомлюваними. Наприклад, групові потреби, як і потреби індивідуальні, усвідомлюються далеко не завжди, на рівні групової свідомості вони здебільшого втілюються в певних інтересах, ціннісних орієнтаціях, переконаннях. Несвідомо люди часто дотримуються й традицій, звичаїв, групових норм поведінки тощо. Проте такі частково неусвідомлювані елементи не належать до найглибших пластів групового несвідомого i, звичайно ж, не вичерпують усього його змісту, який, на думку багатьох представників соціогуманітарних наук, $\epsilon$ багатшим і ширшим від змісту групової свідомості. Тому розглянуті класифікації елементів психіки великих груп потребують доповнення уявленнями - нехай поки що й гіпотетичними - про феномени, специфічні для сфери групового несвідомого як такої.

Наукові уявлення про цю сферу пов'язані насамперед з іменем та ідеями К. Г. Юнга, котрий увів поняття “колективне несвідоме”, зміст якого складають загальні (спільні для всіх людей) апріорні схеми сприйняття світу та поведінки в ньому, що дістали назву архетипів [69]. Учення Юнга добре відоме, тому детально зупинятися на цьому вченні тут не варто. Важливіше підкреслити його значення для сьогодення соціальної психології та іiі дальшого розвитку.

Юнг спеціально не розробляв проблематику психіки великих груп. Проте завжди стверджував, що архетипи потужно виявляють себе в таких формах колективного життя, як міфотворчість, котра притаманна сучасним суспільствам не меншою мірою, ніж стародавнім, у національній та релігійній символіці тощо. Вибір лідерів групового та суспільного рівнів також визначається, згідно з Юнгом, більше змістом колективного несвідомого, ніж утвореннями свідомості (переконаннями, ідеями, уявленнями). Архетип лідера, що втілюється у двох іпостасях “Вождя" і “Шамана", істотно впливає на те, за ким реально готові йти великі групи. При цьому вибір лідера є ірраціональним, важкозрозумілим з погляду логіки, і здійснюється миттєво й беззастережно.

Архетипи мають різний ступінь універсальності. $€$ загальнолюдські архетипи, що втілюють у собі спільність життєвих проблем і досвіду всіх людей на Землі. Але $є$ й архетипи більш специфічні, спільні лише для певної культури, релігії або для певної нації. Як приклад архетипної ситуації в українському контексті розглядають Майдан. Архетипний характер цієї ситуації, що має тенденцію повторюватися за відповідних обставин, зумовлюється ії архаїчністю. Як відомо, в історії України у різні часи практикувалося ухвалення важливих рішень, 
зокрема щодо повалення непопулярного правителя та обрання нового, на велелюдному вічі. Це воскрешає архетипний образ героя-драконоборця. I саме за рахунок своєї архетипності ситуація Майдану щоразу забезпечує іiі учасникам сильні й високі переживання, великий викид психічної енергії, мотивацію до рішучих дій.

Теорія архетипів має, як бачимо, значний, хоч і не безспірний потенціал пояснення і певною мірою передбачення поведінки великих груп, особливо у критичних для суспільства ситуаціях, на переламних етапах історії. Тож не дивно, що оригінальні погляди Юнга породили чимало дочірніх теорій. Серед них помітне місце посідають розроблені представницею української соціально-психологічної науки О. Донченко. Це теорія соиієтальної психіки і теорія психофракталів.

Соцієтальна психіка тлумачиться авторкою як феномен, притаманний великим групам (нації, етносу, територіальній групі тощо) i суспільству в цілому, тобто будь-якій спільноті, будь-якому соціуму, що склався історично протягом достатньо тривалого часу. Цей феномен охоплює неусвідомлювані настановлення на певні, специфічні лише для даної спільноти взірці та форми поведінки, норми реакцій і типи адаптивних процесів. 3 одного боку, він близький до того, що розуміють під поняттям “менталітет”, з другого - має архетипне походження.

Головний зміст цієї теорії становлять уявлення про структуру соцієтальної психіки. Пропонується ії модель, що базується, знову ж таки, на принципі структурної ізоморфності психологічних характеристик індивіда і спільноти. "У моделі соцієтальної психіки, як і у психіці індивіда, - пише О. Донченко, - представлені однакові структурні елементи - властивості, стани і процеси, але їхній зміст та особливості функціонування істотно різняться" [51, с. 4]. Щоправда, ізоморфність запропонованої моделі $\epsilon$, сказати б, умовною. Якщо постульовані соцієтальні властивості (патерни дихотомічних настановлень на кшталт інтровертованості-екстравертованості, раціональності-ірраціональності тощо) ще відповідають загальноприйнятому у психологічній науці розумінню психічних властивостей, то нічим не пов'язані із властивостями соцієтальні стани (конвенційний, коригувальний та хаотичний) уже досить віддалено нагадують власне психічні стани, а соцієтальні процеси (наприклад, ідентифікація, індивідуація чи маргіналізація) взагалі стосуються не групи як цілого, а лише індивідів, що адаптуються до умов її функціонування. На наш погляд, це порушує внутрішню логіку розгортання психічного у груповому вимірі.

Проте теорія соцієтальної психіки все ж надає додаткові можливості для пояснення певних суспільних явищ і має перспективу бодай часткової операціоналізації. На iї основі розроблено опитувальник, за допомогою якого проводить дослідження так звана Українська школа соціальної архетипіки [70; 71]. 
Нові оригінальні уявлення щодо феноменології несвідомої сфери психіки великих груп містить теорія психофракталів, яку О. Донченко розробила пізніше [52]. Терміни “фрактал”, “фрактальний” (від лат. fractus - роздрібнений) означають нерегулярну самоподібність, різномасштабність одного й того самого. У науковий вжиток ці терміни було введено французьким математиком Б. Мандельбро, котрий у 60-70-х роках XX ст. створив фрактальну геометрію. Відтоді фрактали слугують зручними моделями для опису процесів, які раніше вважалися неупорядкованими і такими, що принципово не можуть бути описані.

Теорію психофракталів можна розглядати як одну із цих моделей. Психіка прирівнюється в ній до інформаційно-енергетичної субстанції світобудови. Психофрактал тлумачиться як утілений фрагмент цієї універсальної психіки, призначення якого - функціонувати в ролі глибинного, доцільного, досконалого психічного регулятора, що здатний найбільш адекватно вбудовувати свого носія в те середовище, яке волею долі стає середовищем його існування [52, с. 26-27].

На перший погляд, психофрактали нагадують архетипи. Проте це різні психічні феномени. Психофрактал, як зазначає О. Донченко, $\epsilon$ феноменом ближчим до свідомості, ніж архетип, більш диференційованим, гнучким і більше наближеним до реальності. "Упізнавання" його людьми зазвичай забарвлене позитивними емоціями, а не тими переживаннями “чогось жахливого", які викликає здебільшого “зустріч” 3 архетипом.

Психофрактали поділяються на індивідуальні і соичєтальні. Індивідуальний психофрактал надається людині природою від народження, соцієтальний психофрактал отримує, теж природним чином, кожне невипадкове людське співтовариство в період свого виникнення, у “точці збирання“. Індивідуальний психофрактал функціонує у двох режимах: у “Я”-режимі (втілюється в інстинкті самовиживання індивіда) i "Ми"-режимі (реалізується як інстинкт солідарності зі своєю спільнотою заради іiі виживання). У двох режимах функціонує також соцієтальний психофрактал - у внутрішньому “Ми”-режимі, що стає підгрунтям самоприйняття та самовизнання спільноти (груповий аналог “Я”-режиму), i зовнішньому "Ми”-режимі, від якого залежить характер взаємодії спільноти з іншими груповими суб'єктами (територіальними, етнічними тощо).

Психофрактальність великої групи закріплюється не стільки в її колективній пам'яті, скільки у звичках, стосунках, преференціях, традиціях, почуттях та уявленнях, патернах поведінки. Соцієтальний психофрактал окреслює інтуїтивно зрозумілі людям межі їхньої спільноти (тієї чи тієї великої групи). Він імпліцитно містить у собі метапрограму розвитку спільноти, фундаментальні напрямки ï самоорганізації та функціональної упорядженості. У ньому вбачається об’єктивна, утворена природою і “вбудованими“" в неї людьми, структура шансів спільноти, 
які вона використовує або не використовує. I саме від того, наскільки використовуються ці шанси, залежить психічне здоров'я і соціальна успішність спільноти. Але щоб використати закладені в соцієтальному психофракталі шанси, спільнота має навчитися розпізнавати свій психофрактальний профіль і - тією мірою, якою це можливо - усвідомити його. Одним словом, вона має набути психофрактальної ідентичності.

Не поділяючи беззастережно дискусійних засновків теорії психофракталів (зокрема тверджень про їхнє космічно-польове походження), варто наголосити, однак, що вона має неабиякий евристичний потенціал. Поняття соцієтального психофрактала не лише розширює уявлення про феноменологію несвідомої сфери великих груп, котра зводилася раніше переважно до архетипів, а й надає цій сфері власне групового (колективного, спільнотного) виміру. Того виміру, якого їй не може надати сама по собі теорія архетипів. Адже архетип у його Юнговому тлумаченні є надіндивідуальним (груповим) феноменом лише за походженням, у своєму актуальному існуванні він розподілений між індивідами як членами групи. А тому поняття архетипів у строгому розумінні характеризує велику групу лише з погляду схожості, подібності членів групи, але не з погляду цілісності групи як такої. Цю обмеженість теорії архетипів і долає теорія психофракталів, відображаючи в понятті соцієтального психофрактала аспект цілісності великої групи, принаймні у вимірах групового несвідомого. Міркуючи далі, можна також припустити, що певний функціональний стан соцієтального психофрактала $€$ однією з необхідних умов одночасного “пробудження“" в членів групи певних архетипів у тій чи тій соціальній ситуації.

На цьому вважаємо за можливе завершити наш опис наукових уявлень про складові психіки великих груп. Звичайно, список таких уявлень, як і самих складових, залишається принципово відкритим для доповнень. Але ймовірні доповнення, гадаємо, можна буде “укласти” в загальну логіку здійсненого опису. I тому основних його параметрів це докорінно не змінить.

Висновки. Нормативно закріплені в навчальній літературі підходи до виокремлення та класифікації структурних елементів психіки великих груп (а інших підходів наразі й немає) характеризуються певною однобічністю. Тому наукові уявлення про номенклатуру цих елементів потребують поглиблення і розширення.

У структурі психіки великої групи, точніше в наукових уявленнях про неї, значне місце посідають елементи, що є аналогічними елементам психіки індивіда й описуються, відповідно, загальнопсихологічними термінами (такими як “потреби”, “інтереси”, “очікування”, “настановлення”, “почуття”, “емоції”, “ідентичність” тощо). Ці елементи доцільно розглядати у двох аспектах: 1) як типові для представників певної великої групи; 2) як такі, що бодай почасти мають надіндивідуальний 
характер, тобто властиві лише групі в цілому, а не їі окремим членам (ідентичність групи, потреби групи, інтереси групи і т. ін.).

Поряд із цими “двоаспектними” елементами у структурі психіки великих груп слід виокремлювати групові феномени, що є надіндивідуальними за самою своєю природою. Ідеться передусім про громадську думку, соціальні уявлення (в тлумаченні С. Московічі), історичну (колективну) пам'ять, групові традиції та звичаї. Такі феномени в жодному разі не зводяться до індивідуальних і тому їх можна назвати незвідними.

Проаналізовані наукові уявлення зосереджуються переважно на тих структурних елементах психіки великої групи, котрі належать, 3 одного боку, до класу психічних властивостей, з другого - до групової свідомості. У цьому розумінні нормативно закріплені уявлення про "психологічне обличчя" великих груп є розбалансованими. Тому психологія великих груп має сьогодні спрямувати зусилля на відновлення порушеного балансу, що передбачає пріоритетну увагу до розроблення наукових уявлень: а) про групові психічні стани і групові психічні процеси; б) про сферу групового несвідомого.

Нині в пострадянській соціально-психологічній науці вже склалися певні передумови для формування наукових уявлень про психічні стани великих груп. Мають набути “прав громадянства”, зокрема і в навчальній літературі для студентів, консонантні, дисонантні та конвергентні стани, виокремлені Л. Каширіною, а також стани соціальної напруженості та психологічної мобілізації великих груп, теоретичні та методичні засади вивчення яких розроблено в українській школі соціальної психології.

Певні передумови склались і для розширення наукових уявлень про сферу несвідомого у психіці великих груп. Хоча уявлення про неї залишаються i, мабуть, ще довго залишатимуться гіпотетичними, нині ii можна характеризувати не лише за допомогою поняття архетипів колективного несвідомого, уведеного К. Г. Юнгом. Не без підстав претендує на розвиток юнгівського вчення, а в певному сенсі й на подолання його обмеженості, зокрема, теорія психофракталів О. Донченко, що теж склалася в межах української школи соціальної психології.

Мету, яку ми ставили в цій статті, вважаємо досягнутою. Здійснений опис наукових уявлень про складові психіки великих груп, на нашу думку, можна розглядати як достатню основу для систематизації цих уявлень, у чому і вбачаємо перспективу дальшого розроблення поставленої проблеми.

\section{Список використаних джерел}

1. Слюсаревський, М. М. (2013). Історіогенез соціальної психології як джерело уявлень про іï змістовий обсяг, дисциплінарну побудову та науковий статус. Психологія і суспільство, 2, 45-57.

2. Слюсаревський, М. М. (2015). Соціальна психологія: погляд у минуле в ім'я грядущого. Світогляд, 3 (53), 18-21. 
3. Fiske, S. T., Gilbert, D. T., \& Lindzey, G. (Eds.). (2010). Handbook of Social Psychology. 5th Edition: in 2 vol. New Jersey: John Wiley \& Sons.

4. Московичи, С. (Ред.). (2007). Социальная психология. 7-е изд. Санкт-Петербург: Питер (Серия “Мастера психологии”).

5. Amer, A., \& Howarth. C. (2018). Constructing and contesting threat: representations of white British Muslims across British national and Muslim newspapers. European Journal of Social Psychology, 48 (5), 614-628.

6. Kadianaki, I., \& Andreouli, E. (2017). Essentialism in Social Representations of Citizenship: An Analysis of Greeks' and Migrants' Discourse. Political Psychology, 38 (5), 833-848.

7. Singletona, R., Winskell, K., Nkambule-Vilakatib, S., \& Sabben, G. (2018). Young Africans' social representations of rape in their HIV-related creative narratives, 2005-2014: Rape myths and alternative narratives. Social Science \& Medicine, 198, 112-120.

8. Московичи, С. (1995). Социальные представления: исторический взгляд. Психологический журнал, 16 (1), 3-18.

9. Богомолова, Н. Н., Донцов, А. И., \& Фоломеева, Т. В. (2002). Психология больших социальных групп: новые судьбы, новые подходы. В Г. М. Андреева, А. И. Донцов (Ред.), Социальная психология в современном мире (с. 132-147). М.: Аспект Пресс.

10. Андреева Г. М., (2005) Сочиальная психология : учебник для высших учебных заведений. Москва: Аспект Пресс.

11. Журавлев, А. Л., Соснин, В. А., \& Красников, М. А. (2006). Социальная психология. Москва: Форум: Инфра-М.

12. Губеладзе, І. Г. (2012). Структурно-динамічні особливості соціальної ідентичності сільської молоді в умовах міграції до міста. Наукові студї із сочиільної та політичної психологї, 30 (33), 101-113.

13. Константинов, В. В., \& Вершинина, М. В. (2014). Взаимосвязь этнической идентичности мигрантов-армян и условий их проживания в принимающем сообществе. Психологический журнал, 35 (1), 71-79.

14. Константинов, В. В., Гриценко, В. В., Хухлаев, О. Е., \& Рыжова, С. В. (2018). Структура религиозной идентичности современной православной молодежи. Психологический журнал, 39 (4), 95-104.

15. Кухарук, О. Ю. (2016). Основні теоретичні та емпіричні підходи до вивчення взаємозв'язку етнонаціональної та мовної ідентичностей. Наукові студї із соиіальної та політичної психологї̈, 39 (42), 40-50.

16. Васютинський, В. О. (2014). Три соціально-психологічні парадокси ціннісноорієнтаційного самовизначення носіїв бідності як стилю життя. Наукові студї із соиіальної та політичної психології, 34 (37), 45-56.

17. Гриценко, В. В., \& Ковалева. Ю.В.(2014). Связь ценностей культуры с нормами и типами просоциального поведения русских и белорусов. Психологический журнал, 35 (4), 56-67.

18. Двойнин, А. М. (2011). Специфика ценностно-смысловых ориентаций православной молодежи. Психологический журнал, 32 (5), 23-35.

19. Жадан, І. В. (2014). Базові смисли ціннісної складової політичної картини світу студентства. Наукові студї̈ із сочіальної та політичної психологї, 34 (37), 197-207. 
20. Журавлева, Н. А. (2015). Динамика ценностных ориентаций предпринимателей в условиях макросоциальных преобразований. Психологический журнал, 36 (1), 46-60.

21. Позняков, В. П., \& Никуло, Е. А. (2016). Ценностные ориентации предпринимателей с разным уровнем ответственного отношения к участникам делового взаимодействия. Психологический журнал, 37 (1), 79-88.

22. Пуертас, С. Д. К. (2013). Модуляція особистісних цінностей як чинник формування електорального вибору студентської молоді. Наукові студї̈ із сочіальної та політичної психологї, 32 (35), 227-236.

23. Дроздов, О. Ю. (2014). Психосемантичні особливості геополітичних уявлень української та російської молоді під час міждержавного конфлікту 2014 року. Наукові студії із соиіальної та політичної психологї, 35 (38), 103-112.

24. Емельянова, Т. П. (2006). Конструирование социальных представлений в условиях трансформации российского общества. Москва: Институт психологии РАН.

25. Емельянова, Т. П. (2002). Социальное представление как инструмент коллективной памяти (на примере воспоминаний о Великой Отечественной войне). Психологический журнал, 23 (4), 56-66.

26. Журавлев, А. Л., \& Дробышева, Т. В. (2011). Представления о бедном и богатом человеке как феномен экономического сознания формирующейся личности. Психологический журнал, 32 (5), 46-68.

27. Пащенко-де Превиль, Е., \& Дрозда-Сенковска, Е. (2013). Социальные представления об ответственности у молодежи России и Франции: кросскультурный анализ. Психологический журнал, 34 (2), 87-98.

28. Сіверс, 3.Ф. (2016). Особливості соціальних уявлень та настановлень сучасної молоді щодо політико-правових інститутів. Наукові студіï $i з$ сочіальної та політичної психологї, 37 (40), 62-72.

29. Довгань, Н. О. (2016). Дослідження особливостей ментальності поколінь. Наукові студї із сочіальної та політичної психологї, 39 (42), 115-130.

30. Колесникова, Н. И. (2012). Половозрастные различия в понимании ментальных феноменов в разные периоды взрослости. Психологический журнал, 33 (3), 64-75.

31. Кольцова, В. А., \& Журавлев, А. Л. (2017). Сущностные характеристики и факторы формирования российского менталитета. Психологический журнал, $38(3), 5-17$.

32. Пищик, В. И. (2010). “Потеря” традиционной субъектности поколений как феномен трансформации ментальности. Психологический журнал, 31 (2), $20-27$.

33. Юревич, А. В. (2013). К проблеме базовых компонентов национального менталитета. Психологический журнал, 34 (4), 89-100.

34. Мяленко, В. В. (2010). Образи мови в уявленнях україномовної та російськомовної спільнот. Наукові студї із соціальної та політичної психології, 24 (27), 96-104.

35. Серкин, В. П. (2012). Профессиональная специфика образа мира и образа жизни. Психологический журнал, 33 (4), 78-90.

36. Хотинец, В. Ю., \& Молчанова. Е. А. (2014). Опосредующая роль этнического образа в межэтнических отношениях. Психологический журнал, 35 (3), 40-57. 
37. Остапенко, І. В. (2016). Взаємодія $з$ владою в політичній картині світу студентської молоді. Наукові студї із соціальної та політичної психології, 37 (40), 101-113.

38. Вольфовська, Т. О. (2012). Дослідження історичної пам’яті: концептуальні засади. Проблеми політичної психології та ї̈ роль у становленні громадянина Української держави, 13, 3-12.

39. Блозва, П. І. (2016). Використання молоддю соціального капіталу в процесі становлення політичної культури. Наукові студї із соціальної та політичної психологї̈, 39 (42), 78-92.

40. Найдьонова, Л. А. (2010). Поділений досвід як онтологічна основа рефлексивного капіталу територіальної спільноти. Наукові студї із соиіальної та політичної психології, 24 (27), 62-76.

41. Васютинський, В. О. (2012). Стиль життя як соціально-психологічна характеристика культури бідності. Наукові студї із соиіальної та політичної психологї̈, 30 (33), 19-32.

42. Петрунько, О.В.(2014). Імпліцитні моделі консолідації громадської думки у свідомості студентської молоді. Проблеми політичної психологї, 1 (15), 75-86.

43. Панга, М.В. (2013). Регіональні відмінності ставлення середнього класу України до національної валюти. Наукові студї із соціальної та політичної психологї̈, 32 (35), 70-80.

44. Позняков, В. П., \& Титова, О. И. (2014). Особенности отношений предпринимателей мужчин и женщин к конкуренции и партнерству в деловом взаимодействии. Психологический журнал, 35 (4), 5-17.

45. Сіверс, 3. Ф. (2014). Уявлення молоді про власні права як показник очікувань інституціональної справедливості. Наукові студї із соціальної та політичної психологї, 35(38), 175-186.

46. Бєлавіна, Т. І. (2013). Уявлення осіб з різним економічним статусом щодо правових та етичних норм. Наукові студї̈ із соціальної та політичної психологіï, 32 (35), 45-53.

47. Дроздова, М. А. (2016). Метричні особливості статево-вікових стереотипів жінок. Наукові студї із соиіальної та політичної психології, 39 (42), 151-161.

48. Журавлев, А. Л., \& Юревич, А. В. (2014). Коллективные смыслы как предпосылка личного счастья. Психологический журнал, 35 (1), 5-15.

49. Гулевич, О. А. (2014). Социальные верования и мотивация обучения: роль организационной справедливости. Психологический журнал, 35 (3), 20-28.

50. Васютинський, В. (2010). Психологічні виміри спільноти. Київ: Золоті ворота.

51. Донченко, Е. А. (1994). Социетальная психика. Киев: Наукова думка.

52. Донченко, Е. А. (2005). Фрактальная психология. Доглубинные основания индивидуальной и социетальной жизни. Киев: Знання.

53. Каширина, Л. В. (2004). К проблеме изучения феномена социально-психологических состояний больших социальных групп. Мир психологии, 2 (38), 222-229.

54. Журавлёв, А. Л., \& Емельянова, Т. П. (2009). Психология больших социальных групп как коллективных субъектов. Психологический журнал, 30 (3), $5-15$.

55. Шорохова, Е. В. (2002). Теоретические проблемы исследования больших социальных групп. В А. Л. Журавлев (Отв. ред.), Социальная психология (с. 252-266). Москва: ПЕР СЭ. 
56. Дилигенский, Г. Г. (1996). Сочиильно-политическая психология. Москва: Новая школа.

57. Парыгин, Б. Д. (1999). Социальная психология: проблемы методологии, истории и теории. Санкт-Петербург: ИГУП.

58. Горностай, П. П. (2012). Группа как субъект: соотношение понятий “групповая идентичность” и “идентичность группы”. Психологічні перспективи. Спецвипуск. Т. 1, с. 113-121.

59. Оссовський, В. Л. (1999). Громадська думка: спроба сочіологічної інтерпpетації. Київ: Інститут соціології НАНУ.

60. Слюсаревський, М. М. (2016). Громадська думка з питань освіти: преференції, суперечності та перспективи збагачення. Директор иколи, лічею, гімназії, № 4-6, 48-61.

61. Козловська, Г. В. (2010). Соціологія громадської думки. В В. Б. Свтух (Гол. ред.), Соціологія: Підручник для сочіогуманітарних спеціальностей вищих навчальних закладів (с. 257-270). Київ: Вид-во НПУ ім. М. П. Драгоманова.

62. Заславская Т. (1989). Жить с открытыми глазами. Коммунист, 8, 48-49.

63. Нора, П. (2005). Всемирное торжество памяти. Неприкосновенныий запас. Дебаты о политике и культуре, №2-3 (40-41), 37-51. Взято из http://magazines. russ.ru/nz/2005/2/nora22.html.

64. Хальбвакс, М. (2005). Коллективная и историческая память. Неприкосновенный запас. Дебаты о политике и культуре, №2-3 (40-41), 12-35. Взято $3 \mathrm{http}: / /$ magazines.russ.ru/nz/2005/2/ha2.html.

65. Фуко, М. (1997). История безумия в классическую эпоху. Санкт-Петербург: Университетская книга.

66. Зерній, Ю. (2008). Взаємозв’язок історичної пам'яті та національної ідентичності. Політичний менеджмент, 5, 104-115.

67. Слюсаревський, М. М. (2003). Діагностика, прогнозування та коригування соціальної напруженості: концептуальна модель. Наукові студї із соціальної та політичної психології, 18 (21), 49-69.

68. Блуммер, Г. (2010). Коллективное поведение. Психология масс: Хрестоматия (c. 528-587). Самара: Бахрах-М.

69. Юнг, К. Г. (1991). Архетип и символ. Сост. и вступ. ст. А. М. Руткевича. Москва: Ренесанс.

70. Афонин, Э. А., \& Суший, Е. В. (2011). Архетипика как новое научное направление междисциплинарных исследований проблем государственного управления. Государственное управление в ХХІ веке: традиции и инновации, Материалы 9-й международной конференции (25-27 мая 2011 г.). Ч. 3, с. 111-122. Москва: Изд-во Моск. ун-та.

71. Суший, О. В. (2012). Психологічна культура державного управління. Київ: Світогляд.

\section{References}

1. Slyusarevskyy, M. M. (2013). Istoriohenez sotsialnoi psykholohii yak dzherelo uiavlen pro yii zmistovyi obsiah, dystsyplinarnu pobudovu ta naukovyi status [Historiogenesis of social psychology as a source of ideas about its content, discipline and scientific status]. Psykholohiia i suspilstvo [Psychology and Society], 2, 45-57 (ukr). 
2. Slyusarevskyy, M. M. (2015). Sotsialna psykholohiia: pohliad u mynule v imia hriadushchoho [Social psychology: a look into the past in the name of the future]. Svitohliad [Horizon], 3 (53), 18-21 (ukr).

3. Fiske, S. T., Gilbert, D. T., \& Lindzey, G. (Eds.). (2010). Handbook of Social Psychology. 5th Edition: in 2 vol. New Jersey: John Wiley \& Sons.

4. Moskovichi, S. (Ed.). (2007). Sotsialnaya psikhologiya [Social Psychology]. $7^{\text {th }}$ ed. St. Petersburg: Piter Publ. (Seriya "Mastera psihologii") (rus).

5. Amer, A., \& Howarth. C. (2018). Constructing and contesting threat: representations of white British Muslims across British national and Muslim newspapers. European Journal of Social Psychology, 48 (5), 614-628.

6. Kadianaki, I., \& Andreouli, E. (2017). Essentialism in Social Representations of Citizenship: An Analysis of Greeks' and Migrants' Discourse. Political Psychology, 38 (5), 833-848.

7. Singletona, R., Winskell, K., Nkambule-Vilakatib, S., \& Sabben, G. (2018). Young Africans' social representations of rape in their HIV-related creative narratives, 2005-2014: Rape myths and alternative narratives. Social Science \& Medicine, 198, 112-120.

8. Moskovichi, S. (1995). Sotsialnyye predstavleniya: istoricheskiy vzglyad [Social ideas: historical perspective]. Psikhologicheskiy zhurnal [Psychological Journal], 16 (1), 3-18 (rus).

9. Bogomolova, N. N., Dontsov, A. I., \& Folomeyeva, T. V. (2002). Psikhologiya bolshikh sotsialnykh grupp: novyye sudby, novyye podkhody [Psychology of large social groups: new destinies, new approaches]. In Andreyeva, G.M., \& Dontsov A.I. (Eds.), Sotsialnaya psikhologiya v sovremennom mire [Social psychology in the modern world] (pp. 132-147). Moskow: Aspekt Press Publ. (rus).

10. Andreyeva, G. M. (2005). Sotsialnaya psikhologiya: uchebnik dlya vysshikh uchebnykh zavedeniy [Social psychology: a textbook for higher institutions]. Moskow: Aspekt Press Publ. (rus).

11. Zhuravlev, A. L., Sosnin, V. A., \& Krasnikov, M. A. (2006). Sotsialnaya psikhologiya [Social psychology]. Moskow: Forum: Infra-M Publ. (rus).

12. Hubeladze, I. H. (2012). Strukturno-dynamichni osoblyvosti sotsialnoi identychnosti silskoi molodi v umovakh mihratsii do mista [Structural-dynamic features of social identity of rural youth in conditions of migration to the city]. Naukovi studii iz sotsialnoi ta politychnoi psykholohii [Scientific studios on social and political psychology], 30 (33), 101-113 (ukr).

13. Konstantinov, V. V, \& Vershinina, M. V. (2014). Vzaimosvyaz etnicheskoy identichnosti migrantov-armyan i usloviy ikh prozhivaniya v prinimayushchem soobshchestve [Interrelation of ethnic identity of migrant Armenians and their living conditions in the host community]. Psikhologicheskiy zhurnal [Psychological Journal], 35 (1), 71-79 (rus).

14. Konstantinov, V. V, Gritsenko, V. V., Khukhlayev, O. E., Ryzhova, S. V. (2018). Struktura religioznoy identichnosti sovremennoy pravoslavnoy molodezhi [The structure of the religious identity of modern Orthodox youth]. Psikhologicheskiy zhurnal [Psychological Journal], 39 (4), 95-104 (rus).

15. Kukharuk, O. Yu. (2016). Osnovni teoretychni ta empirychni pidkhody do vyvchennia vzaiemozviazku etnonatsionalnoi ta movnoi identychnostei [Basic theoretical and empirical approaches to the study of the interconnection of ethnonational and linguistic identities]. Naukovi studii iz sotsialnoi ta politychnoi 
psykholohii [Scientific studios on social and political psychology], 39 (42), 4050 (ukr).

16. Vasiutynskyi, V. O. (2014). Try sotsialno-psykholohichni paradoksy tsinnisnooriientatsiinoho samovyznachennia nosiiv bidnosti yak styliu zhyttia [Three socio-psychological paradoxes of value-orientation self-determination of the poverty carriers as a lifestyle]. Naukovi studii iz sotsialnoi ta politychnoi psykholohii [Scientific studios on social and political psychology], 34 (37), 4556 (ukr).

17. Gritsenko, V. V., \& Kovaleva, Yu. V. (2014). Svyaz tsennostey kultury s normami i tipami prosotsialnogo povedeniya russkikh i belorusov [The connection of cultural values with the norms and types of prosocial behavior of Russians and Belarusians]. Psikhologicheskiy zhurnal [Psychological Journal], 35 (4), 56-67 (rus).

18. Dvoynin, A. M. (2011). Spetsifika tsennostno-smyslovyikh oriyentatsiy pravoslavnoy molodezhi [Specificity of value-semantic orientations of Orthodox youth]. Psikhologicheskiy zhurnal [Psychological Journal], 32 (5), 23-35 (rus).

19. Zhadan, I. V. (2014). Bazovi smysly tsinnisnoi skladovoi politychnoi kartyny svitu studentstva [The basic meanings of the value component of the political picture of the world of students]. Naukovi studii iz sotsialnoi ta politychnoi psykholohii [Scientific studios on social and political psychology], 34 (37), 197-207 (ukr).

20. Zhuravleva, N. A. (2015). Dinamika tsennostnykh oriyentatsiy predprinimateley $\mathrm{v}$ usloviyakh makrosotsialnykh preobrazovaniy [Dynamics of value orientations of entrepreneurs in the context of macrosocial transformations]. Psikhologicheskiy zhurnal [Psychological Journal], 36 (1), 46-60 (rus).

21. Poznyakov, V.P., \& Nikulo, E.A. (2016). Tsennostnyye oriyentatsii predprinimateley $\mathrm{s}$ raznym urovnem otvetstvennogo otnosheniya $\mathrm{k}$ uchastnikam delovogo vzaimodeystviya [Value orientations of entrepreneurs with different levels of responsible attitude to the participants of business interaction]. Psikhologicheskiy zhurnal [Psychological Journal], 37 (1), 79-88 (rus).

22. Puertas, S. D. K. (2013). Moduliatsiia osobystisnykh tsinnostei yak chynnyk formuvannia elektoralnoho vyboru studentskoi molodi [Modulation of personal values as a factor in the formation of student youth's electoral choice]. Naukovi studii iz sotsialnoi ta politychnoi psykholohii [Scientific studios on social and political psychology], 32 (35), 227-236 (ukr).

23. Drozdov, O. Yu. (2014). Psykhosemantychni osoblyvosti heopolitychnykh uiavlen ukrainskoi ta rosiiskoi molodi pid chas mizhderzhavnoho konfliktu 2014 roku [Psychosemantic peculiarities of geopolitical views of Ukrainian and Russian youth during the interstate conflict in 2014]. Naukovi studii iz sotsialnoi ta politychnoi psykholohii [Scientific studios on social and political psychology], 35 (38), 103-112 (ukr).

24. Yemelyanova, T. P. (2006). Konstruirovaniye sotsialnykh predstavleniy $v$ usloviyakh transformatsiy rossiyskogo obskchestva [Designing social representations in the transformation of Russian society]. Moskow: Institute of Psychology of RAS (rus).

25. Yemelyanova, T. P. (2002). Sotsialnoye predstavleniye kak instrument kollektivnoy pamyati (na primere vospominaniy o Velikoy Otechestvennoy voyne) [Social representation as a tool of collective memory (on the example of memories of 
the Great Patriotic War)]. Psikhologicheskiy zhurnal [Psychological Journal], 23 (4), 56-66 (rus).

26. Zhuravlev, A. L., \& Drobisheva, T. V. (2011). Predstavleniya o bednom i bogatom cheloveke kak fenomen ekonomicheskogo soznaniya formiruyuscheysya lichnosti [Representations of a poor and rich person as a phenomenon of the economic consciousness of an emerging personality]. Psikhologicheskiy zhurnal [Psychological Journal], 32 (5), 46-68 (rus).

27. Paschenko-de Previl, E., \& Drozda-Senkovska, E. (2013). Sotsialnyye predstavleniya ob otvetstvennosti u molodezhi Rossii i Frantsii: krosskulturnyiy analiz [Social perceptions of responsibility among young people in Russia and France: a cross-cultural analysis]. Psikhologicheskiy zhurnal [Psychological Journal], 34 (2), 87-98 (rus).

28. Sivers, Z. F. (2016). Osoblyvosti sotsialnykh uiavlen ta nastanovlen suchasnoi molodi shchodo polityko-pravovykh instytutiv [Peculiarities of social representations and atittudes of modern youth concerning political and legal institutes]. Naukovi studii iz sotsialnoi ta politychnoi psykholohii [Scientific studios on social and political psychology], 37 (40), 62-72 (ukr).

29. Dovhan, N. O. (2016). Doslidzhennia osoblyvostei mentalnosti pokolin [Research on the peculiarities of generations' mentality]. Naukovi studii iz sotsialnoi ta politychnoi psykholohii [Scientific studios on social and political psychology], 39 (42), 115-130 (ukr).

30. Kolesnikova, N. I. (2012). Polovozrastnyye razlichiya v ponimanii mentalnyikh fenomenov v raznyye periody vzroslosti [Gender and age differences in understanding mental phenomena in different periods of adulthood]. Psihologicheskiy zhurnal [Psychological Journal], 33 (3), 64-75 (rus).

31. Koltsova, V. A., \& Zhuravlev, A. L. (2017). Sushchnostnyye kharakteristiki i faktory formirovaniya rossiyskogo mentaliteta [Essential characteristics and factors of the formation of the Russian mentality]. Psikhologicheskiy zhurnal [Psychological Journal], 38 (3), 5-17 (rus).

32. Piskchik, B. I. (2010). "Poterya" traditsionnoy subyektnosti pokoleniy kak fenomen transformatsii mentalnosti ["Loss" of traditional subjectivity of generations as a phenomenon of mentality transformation]. Psikhologicheskiy zhurnal [Psychological Journal], 31 (2), 20-27 (rus).

33. Yurevich, A. V. (2013). K probleme bazovykh komponentov natsionalnogo mentaliteta [To the problem of the basic components of the national mentality]. Psikhologicheskiy zhurnal [Psychological Journal], 34 (4), 89-100 (rus).

34. Mialenko, V. V. (2010). Obrazy movy v uiavlenniakh ukrainomovnoi ta rosiiskomovnoi spilnot [Images of speeches in the representations of the Ukrainian-speaking and Russian-speaking communities]. Naukovi studii iz sotsialnoi ta politychnoi psykholohii [Scientific studios on social and political psychology], 24 (27), 96-104 (ukr).

35. Serkin, V. P. (2012). Professionalnaya spetsifika obraza mira i obraza zhizni [Professional specificity of the image of the world and lifestyle]. Psikhologicheskiy zhurnal [Psychological Journal], 33 (4), 78-90 (rus).

36. Hotinets, V. Yu., \& Molchanova. E. A. (2014). Oposreduyuschaya rol etnicheskogo obraza $\mathrm{v}$ mezhetnicheskykh otnosheniyakh [The mediating role of the ethnic image in inter-ethnic relations]. Psikhologicheskiy zhurnal [Psychological Journal], 35 (3), 40-57 (rus). 
37. Ostapenko, I. V. (2016). Vzaiemodiia z vladoiu v politychnii kartyni svitu studentskoi molodi [Interaction with authorities in the political picture of the world of student youth]. Naukovi studii iz sotsialnoi ta politychnoi psykholohii [Scientific studios on social and political psychology], 37 (40), 101-113 (ukr).

38. Volfovska, T. O. (2012). Doslidzhennia istorychnoi pam'iati: kontseptualni zasady [Historical memory research: conceptual foundations]. Problemy politychnoi psykholohii ta yii rol u stanovlenni hromadianyna Ukrainskoi derzhavy [Problems of political psychology and its role in the formation of a citizen of the Ukrainian state], 13, 3-12 (ukr).

39. Blozva, P. I. (2016). Vykorystannia moloddiu sotsialnoho kapitalu v protsesi stanovlennia politychnoi kultury [Youth usage of social capital in the process of becoming a political culture]. Naukovi studii iz sotsialnoi ta politychnoi psykholohii [Scientific studios on social and political psychology], 39 (42), 78-92 (ukr).

40. Naidonova, L. A. (2010). Podilenyi dosvid yak ontolohichna osnova refleksyvnoho kapitalu terytorialnoi spilnoty [Shared experience as an ontological basis of the reflexive capital of the territorial community]. Naukovi studii iz sotsialnoi ta politychnoi psykholohii [Scientific studios on social and political psychology], 24 (27), 62-76. (ukr).

41. Vasiutynskyi, V. O. (2012). Styl zhyttia yak sotsialno-psykholohichna kharakterystyka kultury bidnosti [Lifestyle as a socio-psychological characteristic of the poverty culture]. Naukovi studii iz sotsialnoi ta politychnoi psykholohii [Scientific studios on social and political psychology], 30 (33), 19-32 (ukr).

42. Petrunko, O. V. (2014). Implitsytni modeli konsolidatsii hromadskoi dumky u svidomosti studentskoi molodi [Implicit models of consolidation of public opinion in the student youth's consciousness]. Problemy politychnoi psykholohii [Problems of political psychology], 1 (15), 75-86 (ukr).

43. Panha, M. V. (2013). Rehionalni vidminnosti stavlennia serednoho klasu Ukrainy do natsionalnoi valiuty [Regional differences in the attitude of the middle class of Ukraine to the national currency]. Naukovi studii iz sotsialnoi ta politychnoi psykholohii [Scientific studios on social and political psychology], 32 (35), 7080 (ukr).

44. Poznyakov, V. P., \& Titova, O. I. (2014). Osobennosti otnosheniy predprinimateley muzhchin i zhenschin k konkurentsii i partnerstvu v delovom vzaimodeystvii [Features of of male and female entrepreneurs' relationships to competition and partnership in business interaction]. Psikhologicheskiy zhurnal [Psychological Journal], 35 (4), 5-17 (rus).

45. Sivers, Z. F. (2014). Uiavlennia molodi pro vlasni prava yak pokaznyk ochikuvan instytutsionalnoi spravedlyvosti [Young people ideas about their rights as an indicator of institutional justice expectations]. Naukovi studii iz sotsialnoi ta politychnoi psykholohii [Scientific studios on social and political psychology], 35(38), 175-186 (ukr).

46. Bielavina, T. I. (2013). Uiavlennia osib z riznym ekonomichnym statusom shchodo pravovykh ta etychnykh norm [Persons with different economic status ideas on legal and ethical norms]. Naukovi studii iz sotsialnoi ta politychnoi psykholohii [Scientific studios on social and political psychology], 32 (35), 45-53 (ukr).

47. Drozdova, M. A. (2016). Metrychni osoblyvosti statevo-vikovykh stereotypiv zhinok [Metric features of gender-age stereotypes of women]. Naukovi studii iz sotsialnoi ta politychnoi psykholohii [Scientific studios on social and political psychology], 39 (42), 151-161 (ukr). 
48. Zhuravlev, A. L., \& Yurevich, A. V. (2014). Kollektivnyye smysly kak predposylka lichnogo schastya [Collective meanings as a premise for personal happiness]. Psikhologicheskiy zhurnal [Psychological Journal], 35 (1), 5-15 (rus).

49. Gulevich, O. A. (2014). Sotsialnyye verovaniya i motivatsiya obucheniya: rol organizatsionnoy spravedlivosti [Social beliefs and learning motivation: the role of organizational justice]. Psikhologicheskiy zhurnal [Psychological Journal], 35 (3), 20-28 (rus).

50. Vasiutynskyi, V. (2010). Psykholohichni vymiry spilnoty [The psychological dimensions of the community]. Kyiv: Zoloti vorota Publ. (ukr).

51. Donchenko, E. A. (1994). Sotsietalnaya psikhika [Societal psyche]. Kiev: Naukova dumka Publ. (rus).

52. Donchenko, E. A. (2005). Fraktalnaya psikhologiya. Doglubinnyye osnovaniya individualnoy i sotsiyetalnoy zhizni [Fractal psychology. Pre-deep foundation of individual and societal life]. Kiev: Znannya Publ. (rus).

53. Kashirina, L. V. (2004). K probleme izucheniya fenomena sotsialno-psikhologicheskikh sostoyaniy bolshikh sotsialnykh grupp [To the problem of studying the phenomenon of social and psychological states of large social groups]. Mir psikhologii [World of psychology], 2 (38), 222-229 (rus).

54. Zhuravlev, A. L., \& Yemelyanova, T. P. (2009). Psikhologiya bolshikh sotsialnykh grupp kak kollektivnykh subyektov [Psychology of large social groups as collective subjects]. Psikhologicheskiy zhurnal [Psychological Journal], 30 (3), 5-15 (rus).

55. Shorokhova, E. V. (2002). Teoreticheskiye problemy issledovaniya bolshikh sotsialnykh grupp [Theoretical problems of large social groups' research]. In Zhuravlev, A. L. (Ed.), Sotsialnaya psikhologiya [Social Psychology] (pp. 252266). Moskow: PER SE Publ. (rus).

56. Diligenskiy, G. G. (1996). Sotsialno-politicheskaya psikhologiya [Socio-political psychology]. Moskow: Novaya shkola Publ. (rus).

57. Parygin, B. D. (1999). Sotsialnaya psikhologiya: problemy metodologii, istorii $i$ teorii [Social psychology: problems of methodology, history and theory]. St. Petersburg: IPAE Publ. (rus).

58. Gornostay, P. P. (2012). Gruppa kak subyekt: sootnosheniye ponyatiy "gruppovaya identichnost" i "identichnost gruppy" [Group as a subject: the relationship between the concepts of "group identity" and "identity of a group"]. Psykholohichni perspektyvy. Spetsvypusk [Psychological perspectives. Special issue]. T. 1, 113121 (rus).

59. Ossovskyi, V. L. (1999). Hromadska dumka: sproba sotsiolohichnoi interpretatsii [Public opinion: an attempt of sociological interpretation]. Kyiv: Istitute of Sociology of NANU (ukr).

60. Slyusarevskyy, M. M. (2016). Hromadska dumka z pytan osvity: preferentsii, superechnosti ta perspektyvy zbahachennia [Public opinion on education: preferences, contradictions and prospects for enrichment]. Dyrektor shkoly, litseiu, himnazii [Director of school, lyceum, gymnasium], 4-6, 48-61 (ukr).

61. Kozlovska, H. V. (2010). Sotsiolohiia hromadskoi dumky [Sociology of public opinion]. In Yevtukh, V. B. (Ed.), Sotsiolohiia: Pidruchnyk dlia sotsiohumanitarnykh spetsialnostei vyshchykh navchalnykh zakladiv [Sociology: Textbook for sociohumanitarian specialties of higher educational institutions] (pp. 257-270). Kyiv: NPU named after M. Drahomanov (ukr).

62. Zaslavskaya, T. (1989). Zhit s otkrytymi glazami [To live with open eyes]. Kommunist [Communist], 8, 48-49 (rus). 
63. Nora, P. (2005). Vsemirnoye torzhestvo pamyati [World Triumph of Memory]. Neprikosnovennyy zapas. Debaty o politike i kulture [Emergency ration. Debate on Politics and Culture], 2-3 (40-41), 37-51. Retrieved from http://magazines. russ.ru/nz/2005/2/nora22.html. (rus).

64. Halbvaks, M. (2005). Kollektivnaya i istoricheskaya pamyat [Collective and historical memory]. Neprikosnovennyy zapas. Debaty o politike i kulture [Emergency ration. Debate on Politics and Culture], 2-3 (40-41), 12-35. Retrieved from http://magazines.russ.ru/nz/2005/2/ha2.html. (rus).

65. Fuko, M. (1997). Istoriya bezumiya $v$ klassicheskuyu epokhu [The history of insanity in the classical era]. St. Petersburg: Universitetskaya kniga Publ. (rus).

66. Zernii, Yu. (2008). Vzaiemozviazok istorychnoi pamiati ta natsionalnoi identychnosti [Interconnection of historical memory and national identity]. Politychnyi menedzhment [Political management], 5, 104-115 (ukr).

67. Slyusarevskyy, M. M. (2003). Diahnostyka, prohnozuvannia ta koryhuvannia sotsialnoi napruzhenosti: kontseptualna model [Diagnostics, forecasting and correction of social tension: a conceptual model]. Naukovi studii iz sotsialnoi ta politychnoi psykholohii [Scientific studios on social and political psychology], 18 (21), 49-69 (ukr).

68. Blummer, G. (2010). Kollektivnoye povedeniye [Collective behavior]. Psikhologiya mass: Khrestomatiya [Psychology of the masses: Chrestomathy] (pp. 528-587). Samara: Bakhrakh-M Publ. (rus).

69. Yung, K. G. (1991). Arkhetip i simvol [Archetype and symbol]. Moscow: Renesans Publ. (rus).

70. Afonin, E. A., \& Sushiy, E. V. (2011). Arkhetipika kak novoye nauchnoye napravleniye mezhdistsiplinarnykh issledovaniy problem gosudarstvennogo upravleniya [Archetypical studies as a new scientific direction of interdisciplinary research of public administration problems]. In Public administration in the 21st century: traditions and innovations, Proceedings of the 9th International conference (May 25-27, 2011), part 3 (pp. 111-122). Moscow: Moscow University Publ. (rus).

71. Sushyi, O. V. (2012). Psykholohichna kultura derzhavnoho upravlinnia [Psychological culture of governmental management]. Kyiv: Svitohliad Publ. (ukr). 